\title{
Quantification of conjugated linoleic acid and other essential fatty acids in ovine meat, milk, fat, and intestinal digesta
}

\section{Czauderna ${ }^{1}$, J. Kowalczyk ${ }^{1}$, A. Potkański ${ }^{2}$, M. Szumacher-Strabel ${ }^{2}$ and G. Chojecki'}

'The Kielanowski Institute of Animal Physiology and Nutrition,

Polish Academy of Sciences

05-110 Jablonna, Poland

'Department of Animal Nutrition and Feed Management. August Cieszkowski Agricultural University

Wolyniska 33, 60-637 Poznan, Poland

ABSTRACT

Saturated fatty acids (FAs), positional and geometric isomers of mono-, di- and tri-unsaturated FAs containing eighteen carbon atoms were separated on two long $\mathrm{HPLC} \mathrm{RP}+\mathrm{C}_{18}$ columns. All FAs in ovine milk, meat, fat, and intestinal digesta were assayed after pre-column derivatization using UV detection at $256 \mathrm{~nm}$. The content of conjugated linoleic acid (CLA) in processed samples can be determined by using simultaneous UV monitoring at 256 and $235 \mathrm{~nm}$. The presented method is a simple, sensitive and sclective analytical tool for routine quantification of FAs and CLA.

KEY WORDS: fatty acids, conjugated linoleic acid, meat, fat, milk, intestinal digesta, HPLC

\section{INTRODUCTION}

Ruminant fat is an important part of the human diet (Demeyer et al., 1995). In fact, bovine milk fat represents up to $75 \%$ of the total consumption of fat from ruminants. The regulation of the fat composition of milk, adipose tissue, and muscle with the intention of changing fatty acid (FA) profiles, has recently been undertaken primarily to better suit human dietary needs (Demeyer et al., 1995, 1999; Wood et at., 1999; Bas et al., 2000; Chilliard et al., 2000). Indeed, humans require a certain amount of polyunsaturated FAs that are essential for life and health, and 
which cannot be biosynthesized in the body (Nurnberg et al., 1998; Bessa et al., 2000; Chilliard et al., 2000). Moreover, increasing n-3 FAs in milk and meat by feeding grass or fish oil to farm animals improves their value for human nutrition, however, attention must be paid to the potential for an increase in rancidity. Particular emphasis should also be laid on appropriate levels of FAs having potential anti-carcinogenic, anti-atherogenic, or anti-oxidative roles, such as butyric acid, oleic acid, polyunsaturated FAs (especially n-3 FAs), and conjugated linoleic acid (CLA) (Parodi, 1999; Bessa et al., 2000; Chilliard et al., 2000; Mir et al., 2000). On the other hand, certain FAs have a potentially negative effect on human health, such as saturated (C12:0, C14:0 or C16:0) and some trans-fatty acids (Chilliard et al., 2000). FA composition also has a number of effects on the quality of meat, milk and dairy products, including aspects such as physical properties (e.g. melting point or hardness of butter) and organoleptic properties (due to factors such as the effect of oxidative changes in FAs and free short-chain FAs).

Considering the above, it is essential to develop a simple analytical method that provides detailed information on the FA profile of meat, milk, subcutaneous and perirenal fat, and intestinal digesta. HPLC was therefore the procedure of choice for simultaneous separation and quantification of saturated and mono-, di-, and triunsaturated FAs, because the higher temperatures of gas chromatography analysis increase the risk that the double bonds of unsaturated FAs (especially conjugated dienes) will undergo degradation or isomerization (Gutnikov, 1995; Kramer et al., 1997).

\section{MATERIAL AND METHODS}

All chemicals were of analytical grade; organic solvents were of HPLC grade. Acetone, dichloromethane, glacial acetic acid, and acetonitrile were purchased from POCH (Poland). Triethylamine and 2,4'-dibromoacetophenone were from Merck (Germany). Palmitic, stearic acids, CLA and all other cis and/or trans fatty acids were purchased from Sigma (USA). Nonanoic acid (an internal standard) and other saturated FAs were from Fluka. Water used for the preparation of mobile phases and chemical reagents was prepared using an Elix ${ }^{\mathrm{TM}}$ water purification system (Millipore, Canada). The mobile phases were filtered through a $0.45 \mu \mathrm{m}$ membrane filter.

\section{Chromatographic equipment}

An alliance separation module (model 2690 , Waters) with a Waters 996 photodiode array detector was used for the gradient elution system. Data acquisition was performed on an Optimus Pentium III computer with Millennium 2001 software. 
All derivatized FAs were detected at 256 and $235 \mathrm{~nm}$. UV spectra of the eluate with a spectral resolution of $1.2 \mathrm{~nm}$ were obtained every second and were electronically stored on a computer hard disk. Separations were performed on two Nova Pak $\mathrm{C}_{18}$ columns ( $4 \mu \mathrm{m}, 250 \times 4.6 \mathrm{~mm}$ I.D., Waters) in conjunction with a Waters guard $\mathrm{C}_{18}$ column of $10 \times 6 \mathrm{~mm} \mathrm{I.D.}$

\section{Analytical solvents and gradient elution systems}

Solvent A was acetonitrile, while solvent B was water. A binary gradient elution program (Table 1) was used for analysis of all derivatized fatty acids in the assayed samples. All separations were performed at a column temperature of $36^{\circ} \mathrm{C}$. The ambient temperature was $20-23^{\circ} \mathrm{C}$. FA derivative peaks were identified by the retention time of processed standards injected separately and by adding standard

TABLE 1

Binary gradient elution program used for analysis of derivatized fatty acids

\begin{tabular}{|c|c|c|c|c|}
\hline \multirow{2}{*}{$\begin{array}{l}\text { Time } \\
\text { min }\end{array}$} & \multirow{2}{*}{$\begin{array}{c}\text { Flow } \\
\text { rate }\end{array}$} & \multicolumn{2}{|c|}{ Composition, $\%$} & \multirow{2}{*}{ Curve } \\
\hline & & solvent $\mathrm{A}$ & solvent $B$ & \\
\hline 5.0 & 2.4 & 68.0 & 32.0 & 11 \\
\hline 23.0 & 2.4 & 76.5 & 23.5 & 6 \\
\hline 34.5 & 2.7 & 85.0 & 15.0 & 6 \\
\hline 80.9 & 2.7 & 85.0 & 15.0 & 11 \\
\hline 81.0 & 3.0 & 100.0 & 0 & 6 \\
\hline $100.0^{\mathrm{a}}$ & 3.0 & 100.0 & 0 & 11 \\
\hline
\end{tabular}

after 100 min the columns were re-equilibrated for 15 min in $68 \%$ solvent $\mathrm{A}$ and $32 \%$ solvent $\mathrm{B}$ at a flow rate $2.4 \mathrm{ml} / \mathrm{min}$

solutions to biological samples. The concentrations of fatty acids in biological samples were calculated using FA standards and an internal standard (nonanoic acid) as a measure of extraction and derivatization reaction yield. All samples and standards were protected from the light when the reaction components were carried through the hydrolysis and derivatization described below. The limit of detection (LOD) was calculated as a signal-to-noise ratio of 3 , while the limit of quantification (LOQ) was defined as 10 times the noise level (Gratzfeld-Husgen et al., 1994; Meyer, 1999). The background under the peak was calculated from the baseline from the left and right sides of the peak.

Preparation, hydrolysis of samples and derivatization procedure

Milk, meat, subcutaneous and perirenal fat, rumen fluid, and duodenal digesta samples were collected from sheep. All samples were frozen, lyophilized and the 
obtained residues were stored in sealed tubes at $-20^{\circ} \mathrm{C}$ until analyzed. Milk $(\sim 55 \mathrm{mg})$, meat $(\sim 100 \mathrm{mg})$, fat $(\sim 10 \mathrm{mg})$ and intestinal digesta $(\sim 110 \mathrm{mg})$ samples were hydrolyzed with $4.0 \mathrm{~mL}$ of $2 \mathrm{M} \mathrm{NaOH}$ at $85^{\circ} \mathrm{C}$ for $35 \mathrm{~min}$ in sealed tubes. After cooling, the hydrolyzates were acidified with $4 \mathrm{M} \mathrm{HCl}$ to $\mathrm{pH} \sim 2$ and then free fatty acids were extracted four times with $3.5 \mathrm{ml}$ of dichloromethane. The lower organic layer was dried with $\mathrm{Na}_{2} \mathrm{SO}_{4}$ and then the organic solvent was removed under a gentle stream of argon (Heinig et al., 1998). The residue was used for derivatization as below.

To a residue in a reacti-vial, $0.5 \mathrm{~mL}$ of dibromacetophenone $(12 \mathrm{~g} / \mathrm{L}$ in acetone) and $1.5 \mathrm{~mL}$ of triethylamine $(10 \mathrm{~g} / \mathrm{L}$ in acetone) were added (Heinig et al., 1998; Czauderna and Kowalczyk, 2001). The contents were mixed and reacted for $1.5 \mathrm{~h}$ at $50^{\circ} \mathrm{C}$. The derivatization reaction was stopped by adding $50 \mu \mathrm{L}$ of acetic acid ( $2 \mathrm{~g} / \mathrm{L}$ in acetone). The derivatizing procedure for standards was the same as for biological materials. The resulting solutions were injected onto the columns. It is recommended to protect all derivatized samples from the light and to store them at about $-25^{\circ} \mathrm{C}$ when not in use.

\section{RESULTS AND DISCUSSION}

Highly selective and sensitive analytical tools are necessary because of the complexity of the assayed samples. In the previous study, it was shown that geometric and positional isomers of FAs could be satisfactorily separated using columns packed with a strongly hydrophobic silica-based bonded phase. All investigated FAs should be derivatized with dibromoacetophenone into UV-absorbing products (Czauderna and Kowalczyk, 2001), since only conjugated dienes can be directly monitored at $\sim 235 \mathrm{~nm}$ (Heinig et al., 1998). Other underivatized non-conjugated FAs or their methyl esters have high molar absorption only at low UV wavelengths $(\lambda<205 \mathrm{~nm})$ in which many suitable chromatographic mobile phase components are not transparent (Gutnikov, 1995; Heinig et al., 1998). All derivatized FAs were substantially retained on chosen $\mathrm{C}_{18}$-columns and were distinct from other endogenous substances in all assayed samples and from background fluctuation. The total run time of all assayed fatty acids was $85 \mathrm{~min}$ (Figure 1). FA peaks were identified on the basis of the retention time of standards injected separately and by the recovery estimation carried out by addition of FA standards to processed samples. Moreover, saturated FAs were differentiated from unsaturated FAs, conjugated dienes (with emphasis on CLA) and unsaturated non-conjugated FAs by the use of a photodiode array detector (Czauderna and Kowalczyk, 2001). The results of the recovery studies for all quantified FAs are satisfactory (nearly 100\%) and showed that all FA peaks were correctly identified. In the presented HPLC method, the responses of the UV detector to the concentrations of assayed FAs were a linear 


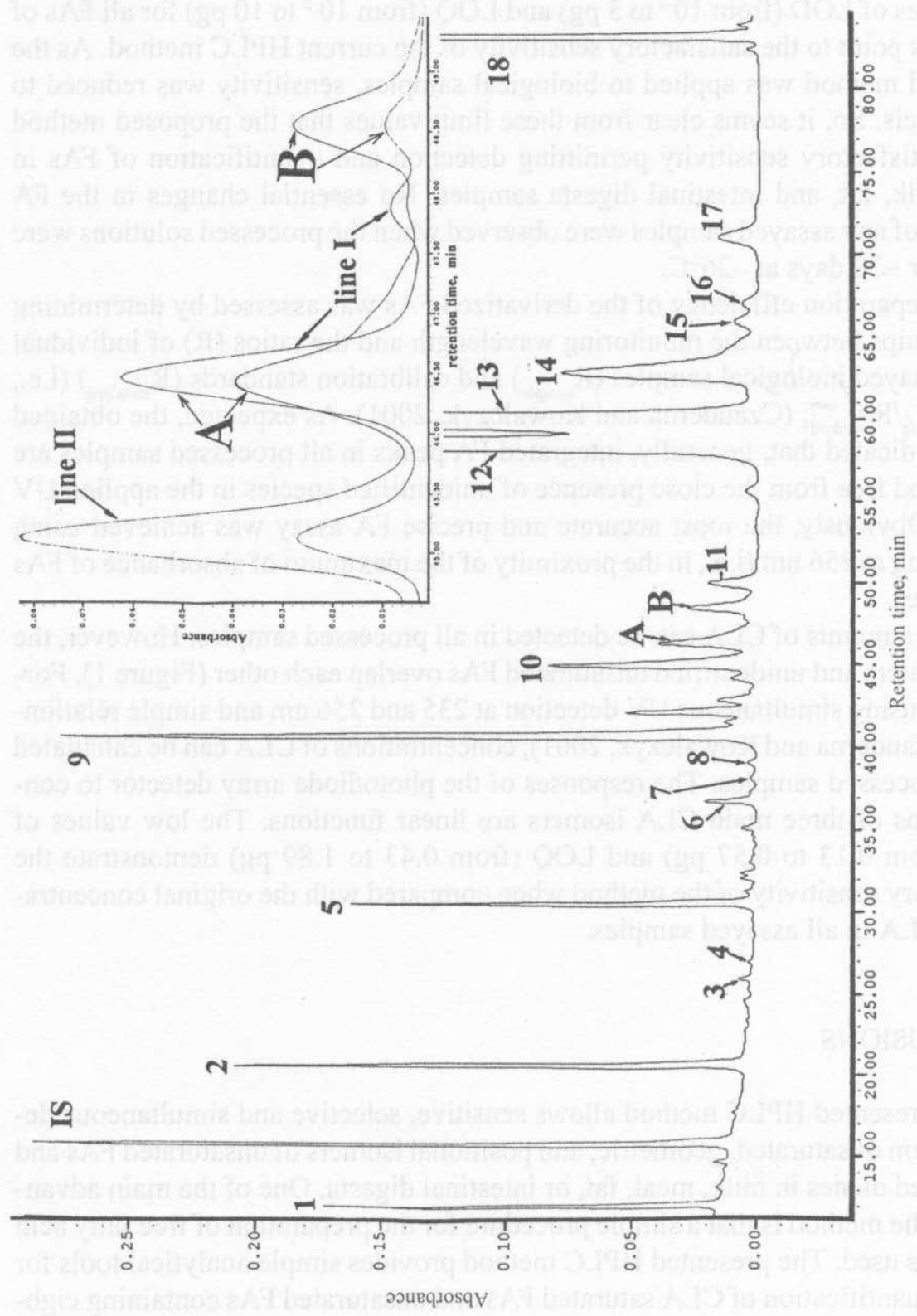

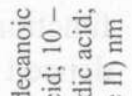

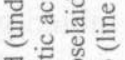

D. कह 迎 । 1 들 - $\sigma=$

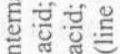
每 \%:ํํำ 1 तु डू से 는 을 응

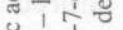
我突

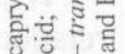
$10<$ iิ 류워 는 $\frac{0}{1}$ 卷人需 - 1 . 造 $n$ 원 돞 \&

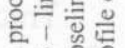
Eb

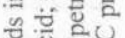
पू 는

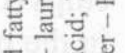
पू⿱ 몰웡 릉 ㅎํำ 늃 존 을 है छั 릉 U 뜬 오월 블.은

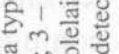
뜸요 원 동.는

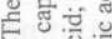
- 1 . 긍 v

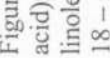


function. Moreover, the correlation coefficients and standard crror in slope evidenced that the proposed UV photodiode array detection at 256 and $235 \mathrm{~nm}$ enabled good linearity of FA derivative quantification in all assayed samples. The low values of LOD (from $10^{-3}$ to $3 \mathrm{pg}$ ) and LOQ (from $10^{-2}$ to $10 \mathrm{pg}$ ) for all FAs of standards point to the satisfactory sensitivity of the current HPLC method. As the presented method was applied to biological samples, sensitivity was reduced to pmol levels. So, it seems clear from these limit values that the proposed method offers satisfactory sensitivity permitting detection and quantification of FAs in meat, milk, fat, and intestinal digesta samples. No essential changes in the FA contents of any assayed samples were observed when the processed solutions were stored for $\sim 30$ days at $-26^{\circ} \mathrm{C}$.

The separation efficiency of the derivatized FAs was assessed by determining relationships between the monitoring wavelength and the ratios $(R)$ of individual FA in assayed biological samples $\left(R_{\text {sample }}\right)$ and calibration standards $\left(R_{\text {standars }}\right)$ (i.e., $\mathrm{R}=\mathrm{R}_{\text {sample }} / \mathrm{R}_{\text {standard }}$; (Czauderna and Kowalczyk, 2001). As expected, the obtained results indicated that, generally, integrated FA peaks in all processed samples are "pure" and free from the close presence of unidentified species in the applied UV ranges. Obviously, the most accurate and precise FA assay was achieved using monitoring at $256 \mathrm{~nm}$ (i.e., in the proximity of the maximum of absorbance of FAs derivative).

Trace amounts of CLA can be detected in all processed samples. However, the CLA isomers and unidentified unsaturated FAs overlap each other (Figure 1). Fortunately, using simultaneous UV detection at 235 and $256 \mathrm{~nm}$ and simple relationships (Czauderna and Kowalczyk, 2001), concentrations of CLA can be calculated in the processed samples. The responses of the photodiode array detector to concentrations of three main CLA isomers are linear functions. The low values of LOD (from 0.13 to $0.57 \mathrm{pg}$ ) and LOQ (from 0.43 to $1.89 \mathrm{pg}$ ) demonstrate the satisfactory sensitivity of the method when compared with the original concentration of CLA in all assayed samples.

\section{CONCLUSIONS}

The presented HPLC method allows sensitive, selective and simultaneous determination of saturated, geometric, and positional isomers of unsaturated FAs and conjugated dienes in milk, meat, fat, or intestinal digesta. One of the main advantages of the method is that a simple procedure for the preparation of free fatty acid extracts is used. The presented HPLC method provides simple analytical tools for routine quantification of CLA saturated FAs and unsaturated FAs containing eighteen carbon atoms. 


\section{REFERENCES}

Bas P., Morand-Fehr P., 2000. Effect of nutritional factors on fatty acid composition of lamb fat deposits. Livest. Prod. Sci. 64, 61-79

Bessa R.J.B., Santos-Silva J., Ribeiro J.M.R. Portugal A.V., 2000. Reticulo-rumen biohydrogenation and the cnrichment of ruminant edible products with linoleic acid conjugated isomers. Livest. Prod. Sci. 63, 201-211

Chilliard Y., Ferlay A., Mansbridge R.M., 2000. Ruminant milk fat plasticity: nutritional control of saturated, polyunsaturated, trans and conjugated fatly acids. Ann. Zootech. 49, 181-205

Czauderna M., Kowalczyk J., 2001. Separation of some mono-, di- and tri-unsaturated fatty acids containing eighteen carbon atoms by HPLC and photodiode array detection. J. Chromatogr. B (in press)

Demeyer D., Van Nevel C., Fiems L., 1995. Composition of meat in relation to processing, nutritional and sensory quality. K. Lundstrom, I. Hansson, E. Wiklund (Editors.). ECCEAMST, Utreclit, pp. 15-36

Demeyer D., Doreau M., 1999. Targets and means for altering meat and milk lipids. Proc. Nutr. Soc. $58,593-607$

Gratzfeld-Husgen A., Schuster R., 1996. HPLC for Food Analysis. Hewlett-Packar (Germany), p. 117

Gutnikov G., 1995. Fatty acid profiles of lipid samples. J. Chromatogr. 67, 71-89

Heinig K., Hissner F., Martin S., Vogt C., 1998. Separation of saturated and unsaturated fatty acids by capillary electrophoresis and HPLC. Amer. Lab., May, 24-29

Kramer J.K.G., Fellner V., Dugan M.E.R., Sauer F.D., Mossoba M.M., Yurawecz M.P., 1997. Evaluating acid and base catalysts in the methylation of milk and rumen fatty acids with special cmphasis on conjugated dienes and total trans tatty acids. Lipids 32, 1219-1228

Meyer V.R., 1999. Practical High-Performance Liquid Chromatography, John Wiley and Sons, Chichester, p. 78

Mir Z., Rushfeldt M.L., Mir P.S., Paterson L.J., Weselake R.J., 2000. Effect of dietary supplementation with either conjugated linoleic acid (CLA) or linoleic acid oil on the CLA content of lamb tissues. Small Ruminant Res. 36, 25-31

Numberg K., Wegner J., Ender K., 1998. Factors influencing fat composition in muscle and pose tissue of farm animals. Livest. Prod. Sci. 56, 145-156

Parodi P.W., 1999. Conjugated linoleic acid and other anticarcinogenic agents of bovine milk fat. J. Daiiry Sci. 82, 1339-1349

Wood J.D., Enser M., Fisher A.V., Nute G.R., Richardson R.I., Sheard P.R., 1999. Manipulating meat quality and composition. Proc. Nutr. Soc. 58, 363-370 


\section{STRESZCZENIE}

Ilościowe oznaczanie sprzężonego kwasu linolowego i innych niezbędnych kwasów tluszczowych w mięsie, mleku, tluszczu i treści jelit owiec

Nasycone kwasy thuszczowe (KT), pozycyjne i geomertryczne izomery mono-, di i tri-nienasycone KT zawierające osiemnaście atomów węgla, rozdzielano na dwóch długich $\mathrm{C}_{18}$ kolumnach z odwróconą fazą. Wszystkie KT w owczym mleku, mięsie, tłuszczu i treści jelitowej oznaczano po przed-kolumnowej derywatyzacji i UV detekcji przy $256 \mathrm{~nm}$. Stosując jednoczesną detekcję przy 235 i 256 nm można oznaczać zawartość sprzężonego kwasu linolowego (SKL) w analizowanych próbkach. Prezentowana metoda jest bardzo prostą, czułą i selektywną analityczną techniką pozwalającą na rutynowe oznaczanie KT i SKL. 